\title{
Successful treatment of COVID-19 infection in a patient with tracheostomy
}

\author{
Miraç ÖZ1 (ID) \\ Aslıhan GÜRÜN \\ $\operatorname{KAYA}^{1}($ ID) \\ Övgü VELIOĞLU \\ YAKUT $^{1}($ ID) \\ Ezgi GÜLTEN $^{2}($ ID) \\ Leyla TALAN ${ }^{3}(I D)$ \\ Serhat EROL ${ }^{1}$ (ID) \\ Fatma ÇiFTCi ${ }^{1}$ (ID) \\ Çağlar UZUN ${ }^{4}$ (ID) \\ Zeynep Ceren \\ KARAHAN $^{5}$ (ID) \\ Neriman Defne \\ ALTINTAS 3 \\ Aydın ÇiLEDAĞ ${ }^{\mathbf{1}}($ ID $)$ \\ Akın KAYA ${ }^{1}$ (ID)
}

${ }^{1}$ Department of Chest Diseases, Ankara University Faculty of Medicine, Ankara, Turkey

${ }^{1}$ Ankara Üniversitesi Tıp Fakültesi, Göğüs Hastalıkları Anabilim Dalı, Ankara, Türkiye

2 Department of Infectious Diseases and Clinical Microbiology, Ankara University Faculty of Medicine, Ankara, Turkey

2 Ankara Üniversitesi Tıp Fakültesi, Enfeksiyon Hastalıkları ve Klinik Mikrobiyoloji Anabilim Dalı, Ankara, Türkiye

${ }^{3}$ Department of Internal Medicine, Division of Intensive Care, Ankara University Faculty of Medicine, Ankara, Turkey

${ }^{3}$ Ankara Üniversitesi Tıp Fakültesi, lç Hastalıkları Anabilim Dalı, Yoğun Bakım Bilim Dalı, Ankara, Türkiye

${ }^{4}$ Department of Radiology, Ankara University Faculty of Medicine, Ankara, Turkey

${ }^{4}$ Ankara Üniversitesi Tıp Fakültesi, Radyoloji Anabilim Dalı, Ankara, Türkiye

${ }^{5}$ Department of Medical Microbiology, Ankara University Faculty of Medicine, Ankara, Turkey

${ }^{5}$ Ankara Üniversitesi Tıp Fakültesi, Tıbbi Mikrobiyoloji Anabilim Dalı, Ankara, Türkiye
Cite this article as: Öz $M$, Gürün Kaya A, Velioğlu Yakut Ö, Gülten E, Talan L, Erol S, et al. Successful treatment of COVID-19 infection in a patient with tracheostomy. Tuberk Toraks 2020;68(4):444-448.

\section{Yazışma Adresi (Address for Correspondence)}

\section{Dr. Miraç ÖZ}

Ankara Üniversitesi Tıp Fakültesi, Göğüs Hastalıkları Anabilim Dalı, ANKARA - TÜRKIYE

e-mail: ozmirac@hotmail.com

CCopyright 2020 by Tuberculosis and Thorax.

Available on-line at www.tuberktoraks.org.com

\section{ABSTRACT}

Successful treatment of COVID-19 infection in a patient with tracheostomy Coronavirus disease 2019 (COVID-19) has been demonstrated to be the cause of emerging atypical pneumonia. In patients with tracheostomy, coronavirus hypothetically coexists with well-known bacterial agents. A 61-yearold male patient with tracheostomy was admitted to the hospital with dyspnea, fever and increased tracheal secretions. Laboratory findings revealed lymphopenia and elevated C-reactive protein and procalcitonin levels. Chest computed tomography showed consolidation areas and ground-glass opacities more prominent in subpleural areas. Although; two consecutive RT-PCR analyses of combined nasopharengeal/oropharengeal swabs were found to be negative for SARS-CoV-2 RNA, positivity was reported for endotracheal aspirate (ETA) sample. Significant growth of Pseudomonas aeruginosa and Stenotrophomonas maltophilia was detected in the bacterial culture of ETA sample. In conclusion, clinical samples for SARS-CoV-2 should be obtained through the lower respiratory tract, if possible and if upper airway samples are negative. To the best our knowledge, our paper is the first report of the patient with tracheostomy who was treated successfully for COVID-19.

Key words: Coronavirus; COVID-19; SARS-CoV-2; RT-PCR; tracheostomy 


\section{ÖZ}

\section{Trakeostomili bir hastada COVID-19 enfeksiyonunun başarılı tedavisi}

Yeni tip Coronavirüs hastalığı (COVID-19) atipik pnömoniye neden olmaktadır. Trakeostomili hastalarda sık karşılaşılan bakteriyel enfeksiyonlarla coronavirüs birlikteliği görülebilmektedir. Olgumuz 61 yaşında trakeostomi ile takip edilen erkek hasta; nefes darlı̆̆ı, ateş ve trakeal sekresyonlarda artış ile hastaneye başvurdu. Laboratuvar bulgularında lenfopeni ve C-reaktif protein ve prokalsitonin düzeylerinde artış saptandı. Toraks bilgisayarlı tomografisinde subplevral alanlarda konsolidasyonlar ve buzlu cam opasiteleri daha belirgin olarak görüldü. Kombine nazofarengeal/orofarengeal sürüntülerin SARS-CoV-2 RNA için RT-PCR analizi ardışık olarak iki kez negatif saptanmasına rağmen endotrakeal aspirat örneğinde pozitiflik görüldü. Endotrakeal aspirat örneğinin bakteri kültüründe Pseudomonas aeruginosa ve Stenotrophomonas maltophilia üremeleri saptandı. Sonuç olarak SARS-CoV-2 için üst hava yolundan alınan örnekler negatifse, mikrobiyolojik örnekler mümkünse alt solunum yolundan alınmalıdır. Olgumuz literatürdeki COVID-19 tanısı ile başarılı olarak tedavi edilen sunulmuş ilk olgudur.

Anahtar kelimeler: Coronavirüs; COVID-19; RT-PCR; SARS-CoV-2; trakeostomi

\section{INTRODUCTION}

A cluster of pneumonia cases with unknown etiology has been announced in Wuhan, China, in December 2019 and this infection spread rapidly worldwide and caused a pandemic. The pathogen of this infection is a novel coronavirus, and is named as "severe acute respiratory syndrome coronavirus-2 (SARS-CoV-2)" (1). The disease that SARS-CoV-2 causes is called the "Coronavirus Disease 2019 (COVID-19)" (1). The gold standard test for the diagnosis of COVID-19 is the detection of SARS-CoV-2 RNA in the respiratory samples by reverse transcriptase-polymerase chain reaction (RT-PCR) analysis (1). Clinical and radiological findings, especially chest computed tomography (CT), are also important in the diagnosis of COVID-19 due to the possibility of false negative results by RT-PCR (1). Tracheostomy is applied to nearly $10 \%$ of critical care patients who require prolonged mechanical ventilation. Tracheostomy usually increases the risk for pneumonia and bacterial colonization in the lower respiratory tract (2). Ventilator-associated pneumonia (VAP) is related to the endotracheal tube or the tracheostomy tube (2). The prolonged ventilated patients have a higher risk for nosocomial pneumonia and VAP (3). In tracheostomized patients, bacterial proliferation of normal flora as well as virulent pathogens is frequent and the most common pathogen is Pseudomonas aeruginosa (4). Here we report a tracheostomized COVID-19 patient with bacterial superinfection. The patient was diagnosed with a positive SARS-CoV-2 RT-PCR testing of endotracheal aspirate (ETA) sample after two consecutive negative RT-PCR results obtained from combined nasopharengeal/oropharengeal (NP/OP) swabs.

\section{CASE REPORT}

Hereby, we present a case of a 61-year-old man with a medical history of chronic obstructive pulmonary disease (COPD), bronchiectasis, previous tuberculosis, and bilateral upper lobectomies nearly 30 years ago. He had a tracheostomy and had been ventilating with a home-type of mechanical ventilator for two years.

The patient was admitted to the hospital with shortness of breath, fever, and increased tracheal secretions for the last two weeks. The patient had neither traveled outside of Turkey nor had been exposed to anyone with suspected or confirmed diagnosis of COVID-19. Physical examination was remarkable for ronchi bilaterally. Heart sounds were normal. His vital signs included a temperature of $37.8^{\circ} \mathrm{C}$, blood pressure of $110 / 75 \mathrm{mmHg}$, heart rate of $87 /$ minute, respiratory rate of $21 /$ minute, saturation of $90 \%$ on MV with SIMV mode and $\mathrm{FiO}_{2} 50 \%$. Laboratory results were as follows; white blood cell count (WBC) of $15.02 \times 10^{9} / \mathrm{L}$, a hemoglobin $(\mathrm{Hb})$ level of $11.6 \mathrm{~g} / \mathrm{dL}$, a lymphocyte count of $0.21 \times 10^{9} / \mathrm{L}$, and a platelet count of $20^{3} \times 10^{9} / \mathrm{L}$. A large cavity at upper zone of the right lung and heterogenous opacities at middle and lower zones of the both lungs were seen on chest X-ray (Figure 1A). Chest CT showed bilateral peripheral multifocal rounded consolidation and ground glass opacities (GGO) and tree in bud opacities with centrilobular nodules. Also there was a cavity at lateral basal segment of the right lower lobe The peripheral and multifocal rounded consolidation and GGO are the typical findings of COVID-19 pneumonia. The other findings are atypical for COVID-19 pneumonia and point to a bacterial, mycobacterial or viral infection other than COVID-19 pneumonia (Figure 2). Parenteral antibiotic treatment 


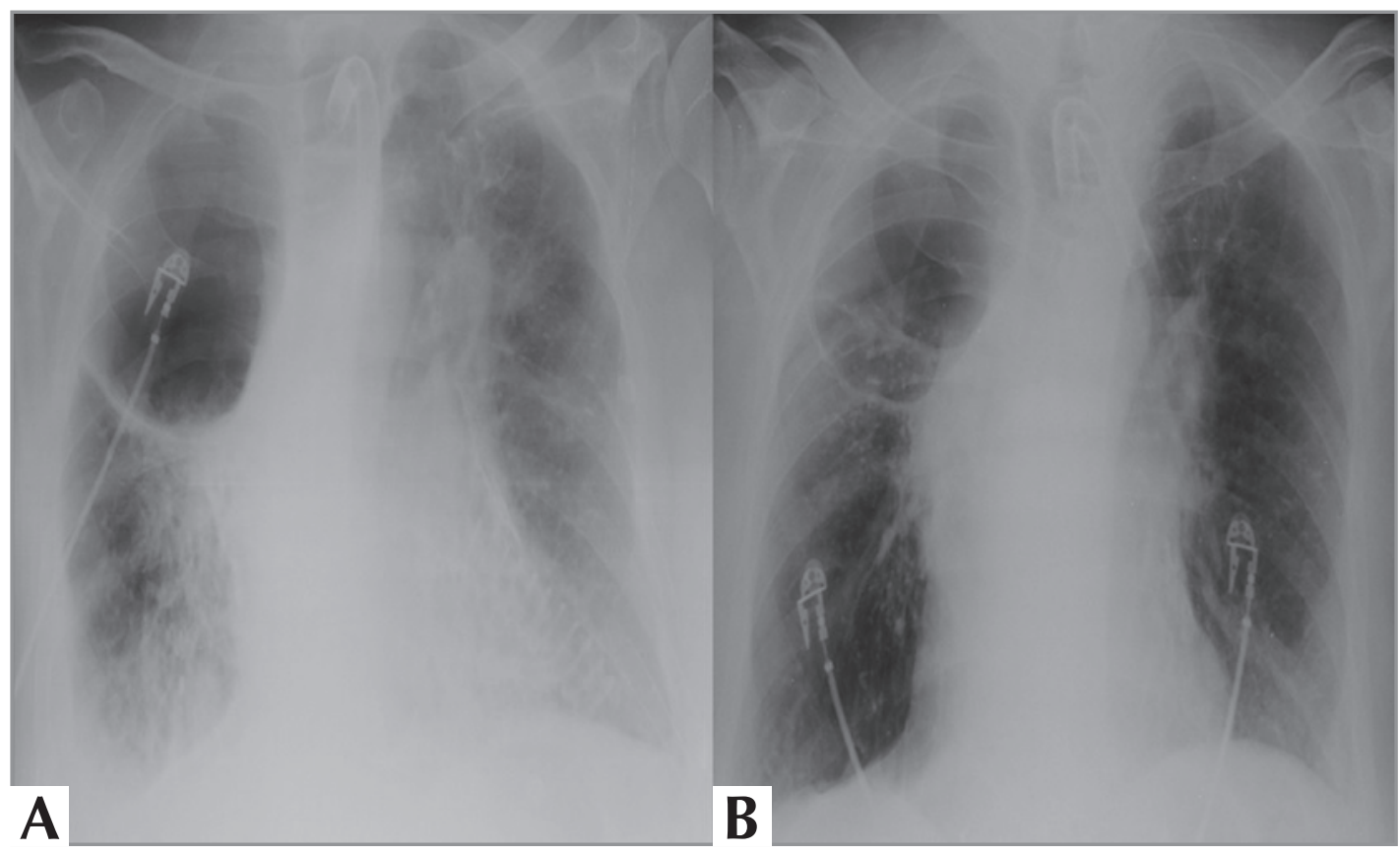

Figure 1. On the first day of admission chest X-ray shows bilateral multifocal patchy airspace opacities, bilateral minimal pleural effusion and a large thick-walled cavity at the upper zone of the right lung A. After treatment chest X-ray reveals the decrease of multifocal patchy infiltrates and bilateral pleural effusion $\mathbf{B}$.

was initiated empirically. SARS-CoV-2 RT-PCR analysis of two consecutive combined NP/OP swabs was reported negative. Even though RT-PCR results were negative twice, the patient was considered compatible with COVID-19 pneumonia with radiological and clinical features. Therefore; he was accepted to the intensive care unit (ICU) and isolated. Rapidly; hydroxychloroquine $200 \mathrm{mg}$ b.i.d. and azithromycin $500 \mathrm{mg}$ q.i.d were initiated for probable COVID-19 and piperacillin/tazobactam were started empirically owing to a probable bacterial co-infection. By the tracheostomy cannula, mechanical ventilation was continued. Subcutaneous low molecular weight heparin (LMWH, enoxaparin) $6000 \mathrm{U}$ b.i.d was applied. After two days, he deteriorated clinically. He had subfebrile fever, tachypnea and was hypotensive with need of vasopressors. CRP and procalcitonin levels had increased, so ETA bacterial culture and viral PCR examinations were repeated. Antibiotic regimen was escalated, meropenem treatment was initiated. Pseudomonas aeroginosa $>10^{5} \mathrm{CFU} / \mathrm{mL}$ was cultured on microbiological examination. SARS-CoV-2 RT-PCR analysis of the ETA sample was also found to be positive. After PCR positivity, favipravir 1600 mg was administered orally twice daily on day 1 , then $600 \mathrm{mg}$ orally twice daily. Hydroxychloroquine, azithromycin and favipravir therapy was continued for five days. Seven days later, the patient had fever and was worsened clinically, despite suitable antimicrobial treatment for bacterial infection. CRP and procalcitonin levels increased to $250 \mathrm{mg} / \mathrm{L}$ and $32 \mathrm{ng} / \mathrm{mL}$, respectively. Bacterial culture and RT-PCR test for SARSCoV-2 from ETA were repeated. Bacteriological culture revealed the growth of $>10^{5} \mathrm{CFU} / \mathrm{mL}$ Acinetobacter baumannii, while colony count of Pseudomonas aeroginosa was decreased to $<10^{4}$ $\mathrm{CFU} / \mathrm{ml}$. So, intravenous colistin $300 \mathrm{mg}$ was administered once daily on day 1 , then $150 \mathrm{mg}$ twice daily and intravenous phosphomycine 6 gr was added three times daily. Nearly three days later, the patient's fever dropped to normal levels, and $\mathrm{FiO}_{2}$ level was reduced to $30 \%$. Under the ongoing antibiotic regimen, the patient's clinical and radiological findings were stable. On the $27^{\text {th }}$ day, regression of lesions was observed on chest X-ray (Figure 1B).

\section{DISCUSSION}

Numerous case reports and studies have been published with the rapid spread of COVID-19 worldwide. In this way, new approaches to the diagnosis and treatments of the disease are being developed. 


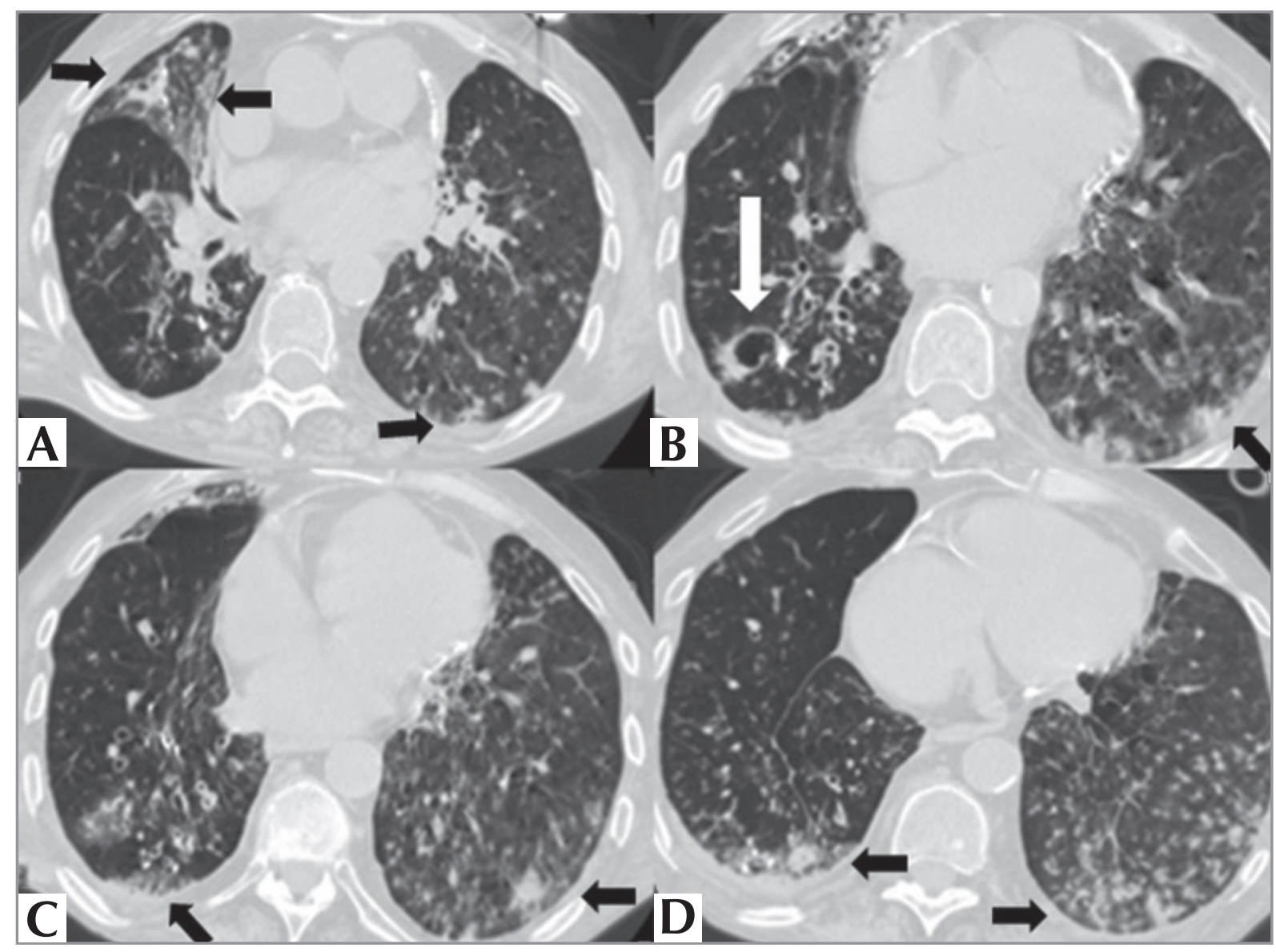

Figure 2. Axial CT images of the lungs show bilateral peripheral rounded consolidations with surrounding GGO (black arrows), a thick-walled small cavity at the lateral basal segment of the right lower lobe (white arrow) (B) and tree in bud opacities (A-D). The peripheral and multifocal rounded consolidation and GGO are the typical findings of COVID-19 pneumonia. The other findings are atypical for COVID-19 pneumonia and point to a bacterial, mycobacterial or viral infection other than COVID-19 pneumonia.

Single or combined NP/OP swabs are commonly used for diagnostic testing of COVID-19 (6). However, when clinical and radiological suspicion is high, negative RT-PCR test results of upper respiratory specimens may not be enough to rule out COVID-19 (5) SARS-CoV-2 can typically be detected in the NP swab of patients with COVID-19 in early stages of the disease, so RT-PCR test positivity is usually identified during these days. If only NP/OP samples are taken after the first few days of the disease, SARS-CoV-2 RT-PCR may be found positive $(6,7)$. In our patient, who was on mechanical ventilation by tracheostomy, we found positive RT-PCR result for SARS-CoV-2 on endotracheal aspirate sample.

Laboratory findings of our patient were similar with COVID-19 cases on literature such as lymphopenia, increased CRP level and white blood cell count (8).
Gradual increase in procalcitonin levels suggested the presence of bacterial infection, as it is usually found in normal ranges in patients with viral infections (9). Procalcitonin levels in our case were high and it was compatible with bacterial infections.

RT-PCR analysis of viral RNA is regarded as the reference standard test in COVID-19 diagnosis; although, research have showed the prominence of chest CT in patients with false negative RT-PCR results and reported the CT sensitivity as $98 \%$ (10). Bilateral round-shaped ground glass opacities with or without consolidation at posterior and peripheral lungs were the most important diagnostic findings of COVID-19 at chest CT (10). Presence of centrilobular nodules, tree in bud appearance and cavity suggest a bacterial, mycobacterial and viral infection other than COVID-19 pneumonia or superinfection as we have seen in our patient (11). 
Tracheostomy is a risk factor for bacterial infections or colonization especially in mechanically ventilated patients (12). In a study which evaluated 952 patients who were mechanically ventilated, revealed the growth of Pseudomonas aeruginosa, Escherichia coli, Klebsiella pneumoniae, Staphylococcus species, and Acinetobacter species from their endotracheal aspirates. In this study the investigators have found that the mortality rate was significantly higher in VAP patients than in non-VAP cases (13). In our patient, we cultured multiple etiological agents of hospital-acquired bacterial infections such as Pseudomonas aeruginosa and Acinetobacter baumannii following COVID-19 diagnosis.

\section{CONCLUSION}

Frequent aspiration of secretions through the tracheostomy cannula suggests that first entry of infection could be lower respiratory tract. For this reason, if NP/OP samples are negative for SARS-CoV-2, swabs taken for the evaluation of SARS-CoV-2 RNA in the patients with tracheostomy should be obtained from the lower respiratory tract. We suggest that when a tracheostomized patient is encountered, the diagnosis of COVID-19 should not only be relied on the RT-PCR analysis of NP/OP samples, lower respiratory tract specimens should be evaluated if NP/OP samples are negative.

Furthermore, coinfection or superinfection with SARS-CoV-2 and/or resistant bacteria could worsen the disease in mechanically ventilated patients with tracheostomy. So, we suggest that super-infection should be considered in these patients and ETA samples should be evaluated for both viral and bacterial pathogens. Hydroxychloroquine, azytromycine and favipiravir treatment were adequate to treat our COVID-19 patient. In the presence of bacterial agent, appropriate broad-spectrum antibiotics should be added to the treatment regime early. To the best our knowledge, despite the fact that there are many cases in the literature about surgical tracheostomy management in COVID-19 patients, our paper is the first report of a patient with tracheostomy who was successfully treated for COVID-19.

\section{CONFLICT of INTEREST}

The authors reported no conflict of interest related to this article.

\section{AUTHORSHIP CONTRIBUTIONS}

Concept/Design: MÖ, AGK, FÇ, AK

Analysis/Interpretation: MÖ, AGK, ÖVY, EG, LT

Data Acquisition: ÖVY, SE, EG, LT

Writting: MÖ, AGK, FÇ

Critical Revision: ÇU, ZCK, NDA, AÇ

Final Approval: MÖ, AGK, SE, FÇ, AÇ, AK

\section{REFERENCES}

1. Feng H, Liu Y, LV M, Zhong J. A case report of COVID-19 with false negative RT-PCR test: necessity of chest CT. Japan J Radiol 2020; 38(5): 409-10.

2. Frutos-Vivar F, Esteban A, Apezteguia C, Anzueto A, Nightingale $P$, Gonzalez $M$, et al. Outcome of mechanically ventilated patients who require a tracheostomy. Crit Care Med 2005; 33(2): 290-8.

3. Epstein SK. Late complications of tracheostomy. Respir Care 2005; 50(4): 542-9.

4. Eid RC, Domingues F, Silva Barreto JK, Marra AR, Silva CV, Paes AT, et al. Successful prevention of tracheostomy associated pneumonia in step-down units. Am I Infect Control 2011; 39(6): 500-5.

5. Hase $R$, Kurita $T$, Muranaka $E$, Sasazawa $H$, Mito $H$, Yano $Y$. A case of imported COVID-19 diagnosed by PCR-positive lower respiratory specimen but with PCR-negative throat swabs. Infect Dis (London, England) 2020; 52(6): 423-6.

6. Mawaddah A, Gendeh HS, Lum SG, Marina MB. Upper respiratory tract sampling in COVID-19. The Malays J Pathol 2020; 42(1): 23-35.

7. Pan Y, Zhang D, Yang P, Poon LL, Wang Q. Viral load of SARS-CoV-2 in clinical samples. Lancet Infect Dis 2020; 20(4): 411-2.

8. Lippi G, Plebani M. Laboratory abnormalities in patients with COVID-2019 infection. Clin Chem Lab Med 2020; 58(7): 1131-4.

9. Lippi G. Sepsis biomarkers: past, present and future. Clin Chem Lab Med 2019; 57(9): 1281-3.

10. Ye Z, Zhang $Y$, Wang $Y$, Huang $Z$, Song B. Chest CT manifestations of new coronavirus disease 2019 (COVID-19): a pictorial review. Eur Radiol 2020: 1-9.

11. Hani C, Trieu NH, Saab I, Dangeard S, Bennani S, Chassagnon G. COVID-19 pneumonia: A review of typical $C T$ findings and differential diagnosis. Diagn Interv Imaging 2020; 101(5): 263-8.

12. Sole ML, Talbert S, Penoyer DA, Bennett M, Sokol S, Wilson J. Comparison of respiratory infections before and after percutaneous tracheostomy. American journal of critical care: an official publication. Am Crit Care Nurs 2014; 23(6): e80-7.

13. Pawar M, Mehta Y, Khurana P, Chaudhary A, Kulkarni V, Trehan N. Ventilator-associated pneumonia: Incidence, risk factors, outcome, and microbiology. I Cardiothorac Vasc Anesth 2003; 17(1): 22-8. 